\title{
PEMANFAATAN GEOFENCE UNTUK MENCARI LOKASI BENGKEL TAMBAL BAN TERDEKAT BERBASIS ANDROID
}

\author{
Wildan Azzami ${ }^{1}$, Anggraini Kusumaningrum ${ }^{2}$, Sudaryanto ${ }^{3}$ \\ Departemen Informatika \\ Sekolah Tinggi Teknologi Adisutjipto Yogyakarta \\ Jl. Janti, Blok-R, Lanud Adisucipto Yogyakarta \\ azzamiwildan25@gmail.com ${ }^{1}$,anggraini@stta.ac.id ${ }^{2}$, sudaryanto@stta.ac.id ${ }^{3}$
}

\begin{abstract}
The number of vehicles in Indonesia continues to increase every year. It will also be directly proportional to many people who have problems with their vehicles, such as finding a tire leaking from a nail puncture or other causes. And will also increase the need for tire services. For vehicle users who do not know the area around when experiencing leak tire disaster, then directly proportional to search for the nearest tire repair shop will be difficult. Therefore, in this study developed information media in the form of Android-based applications to map the locations workshop tire repair shop, as well as search for the nearest tire patch based on the location of the rider by using geofence system, where in this application the user will be notified the nearest workshop with a blink on the animated image tire repairs. From the test results, this application is able to help users search for the nearest tire repair shop along with the distance from the user location. This application is also able to show related information as well as showing the distance and route of the road that will be taken from the location of the user with the location of the intended tire patch by utilizing google maps applications. Applications have been tested by questionnaire method distributed to 30 respondents with 10 questions and the results of the questionnaire calculated using the likert scale get 76,2\% results and included in either category
\end{abstract}

Keywords: Tire patch, Applications, Android, Geofence,

\section{Pendahuluan}

Kendaraan bermotor merupakan alat yang paling dibutuhkan sebagai media transportasi. Salah satu faktor yang dapat mengkibatkan masalah dalam berkendara adalah mendapati ban kendaraan bocor dijalan karena tertusuk paku, terkena lobang pada jalan, ataupun sebab lain. Hal tersebut mempengaruhi kebutuhan akan layanan kendaraan bermotor seperti bengkel tambal ban. Aplikasi pencarian tambal ban terdekat dengan memanfaatkan geofence berbasis Android ini bertujuan untuk membantu masyarakat dalam pencarian tambal ban.

Pada penelitiannya Anwar (2014) menggunakan sistem Location Based Service (LBS) untuk aplikasi pencarian orang yang tersesat berbasis Android. Nataliana (2013) dalam penelitiannya dirancang sebuah sistem penjejakan mandiri (personal tracking) yang menggunakan teknologi SMS sebagai media pengiriman paket data koordinat posisi. Namiot (2014) dalam penelitian tentang geofence and network proximity menjelaskan geofence merupakan sistem yang dapat menganalisa dan melacak posisi pengguna secara otomatis dan memberi laporan kapanpun dan dimanapun selama pengguna keluar dan masuk dalam area Geofence yang sebelumnya sudah ditentukan oleh pemakai sistem GPS ini. Sigit (2015) Geofence merupakan suatu prosedur untuk mengidentifikasi jika lokasi terletak dalam pagar tertentu, misalnya batas lingkungan, wilayah kehadiran di mal, toko, warung makan.

\section{Metode Penelitian}

\subsection{Geofence}

Geofence adalah teknologi yang mendefinisikan batas virtual di sekitar wilayah geografis dunia nyata. Radius yang ditetapkan dapat memicu tindakan ditelepon atau perangkat elektronik 
portabel lainnya. Geofence memungkinkan lansiran otomatis yang akan dihasilkan berdasarkan koordinat yang diitetapkan wilayah geografis.

\subsection{Location Based Service (LBS)}

Location based services adalah layanan berbasis lokasi atau istilah umum yang sering digunakan untuk menggambarkan teknologi yang digunakan untuk menemukan lokasi perangkat yang pengguna gunakan. Layanan ini menggunakan teknologi global positioning service (GPS) dan cell-based location dari Google.

\section{Perancangan Sistem}

\subsection{Arsitektur Jaringan}

Arsitektur jaringan digunakan untuk mengambarkan arsitektur sistem secara menyeluruh.

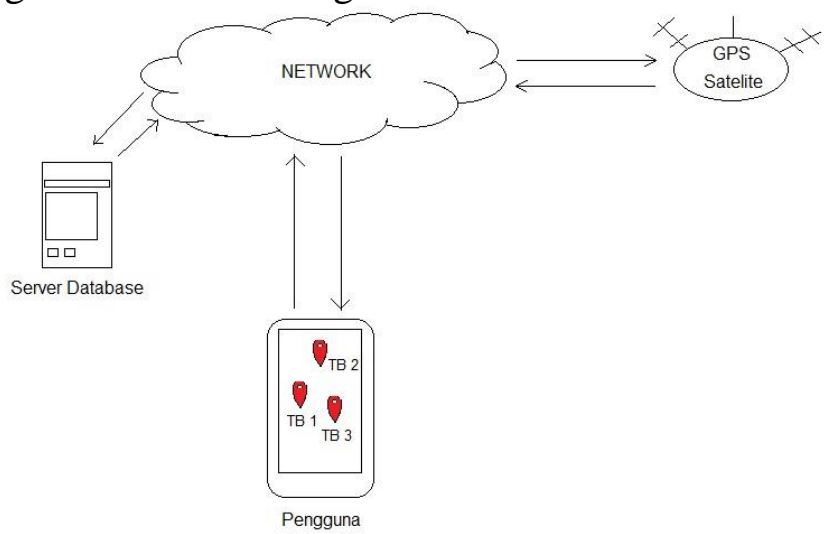

Gambar 1 Arsitektur Jaringan

Pada Gambar 3.1 dilihat keterkaitan antara beberapa pendukung dari aplikasi pencarian lokasi tambal ban. Server database adalah sebuah perangkat yang terhubung dengan internet yang digunakan untuk menyimpan database lokasi tambal ban. Smartphone pengguna terhubung ke jaringan internet untuk mengakses server database untuk mengambil data dan melakukan pencarian lokasi terdekat dengan GPS yang juga terhubung ke jaringan internet.

\subsection{Use Case Diagram}

Use case diagram pada aplilkasi pencarian tambal ban pengguna tidak dibatasi aksesnya terhadap aplikasi ini. Pengguna dapat menambahkan informasi baru terkait tambal ban. Sedangkan admin dapat menghapus data.

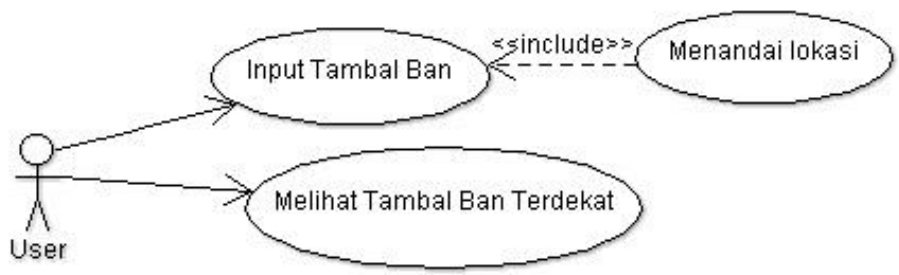

Gambar 2 Use Case Diagram User

Pada Gambar 2 menjelaskan user dalam satu sesi dapat melihat tambal ban terdekat dan melakukan penginputan data tambal ban baru. 


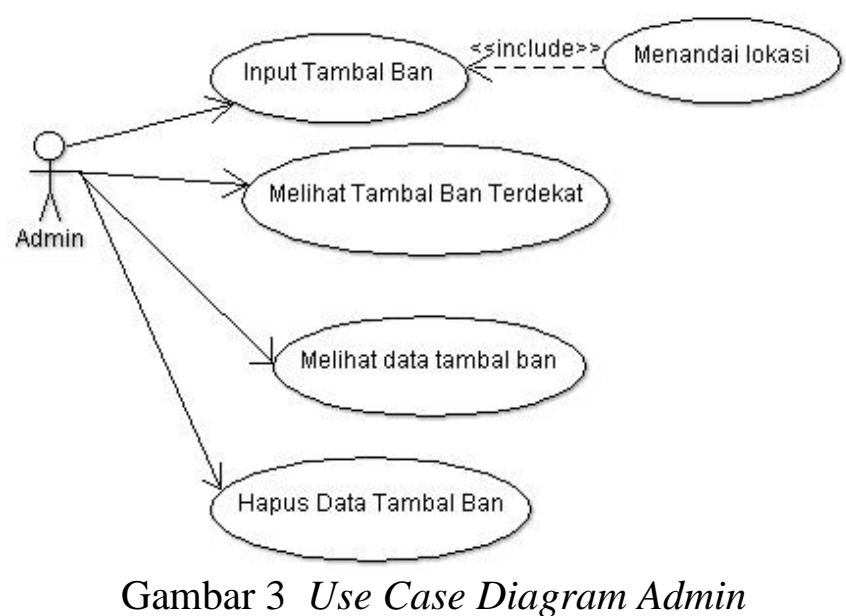

Sedangkan pada Gambar 3 menjelaskan admin dapat memiliki sebuah halaman admin yang dapat menampilkan data tambal ban untuk mengkoreksi data tambal ban yang tersimpan di server database.

\subsection{Activity Diagram}

Diagram aktifitas digunakan untuk memberikan informasi mengenai alur proses yang dilakukan oleh pengguna dalam penggunaan aplikasi ini. Pertama-tama aplikasi akan mengecek GPS pada smartphone hidup atau mati. Jika GPS dalam kondisi mati akan ada konfirmasi dari aplikasi untuk menghidupkan GPS. Setelah GPS dipastikan hidup maka aplikasi akan mencari posisi dari pengguna dan mengambil data tambalban diserver. Setelah data diterima oleh aplikasi, aplikasi akan mencari tambalban terdekat dan membuat marker dari lokasi tambalban berkedip.

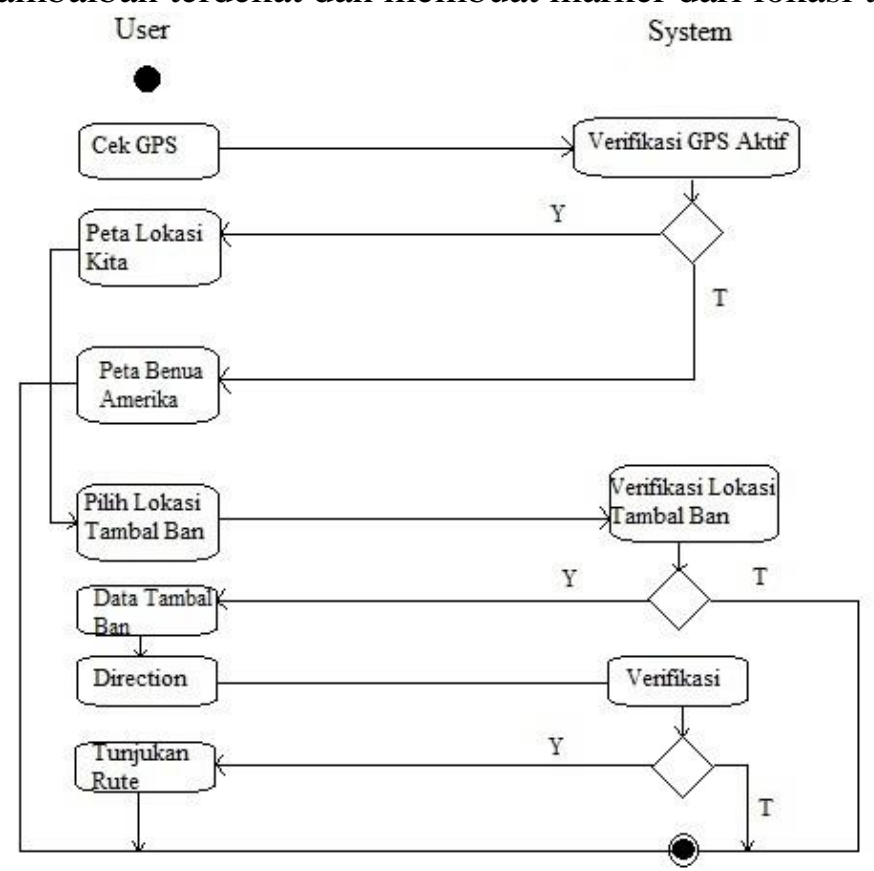

Gambar 4 Activity diagram

\section{Hasil Dan Pembahasan}

\subsection{Tampilan Lokasi Tambal Ban} diinputkan.

Pada Gambar 4 menampilkan tampilan lokasi-lokasi bengkel tambal ban yang sudah 


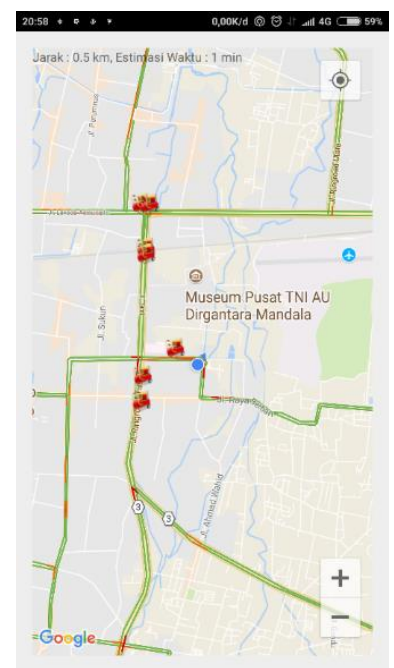

Gambar 5 Tampilan Aplikasi Admin

\subsection{Tampilan Form Tambah Tambal Ban Baru}

Pada Gambar 5 merupakan tampilan dari form penambahan data bengkel tambal ban.

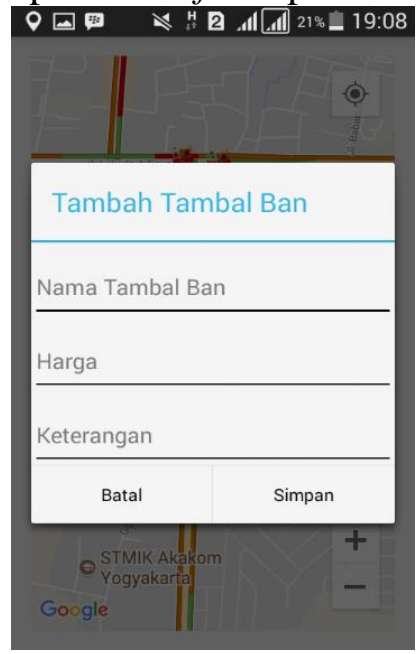

Gambar 6 Tampilan Form Tambah Bengkel Tambal Ban

\subsection{Pengujian}

\subsubsection{Uji Coba Versi Android}

Pada tabel 1 menampilkan pengujian aplikasi pada versi android yang sudah dicoba dan berhasil.

Tabel 1 Pengujian Versi Android

\begin{tabular}{|l|l|l|l|}
\hline No. & Versi Android & Berhasil & Tidak Berhasil \\
\hline 1. & 4.4 .2 / Kitkat & V & \\
\hline 2. & 5.0 .2 / Lolipop & V & \\
\hline 3. & 6.0 / Marshmellow & V & \\
\hline 4. & 7.0 / Nougat & V & \\
\hline
\end{tabular}

Dilihat dari tabel 1 pengujian versi Android didapatkan kesimpulan bahwa aplikasi ini dapat berjalan dengan baik pada system operasi Android versi 4.4 keatas. 


\subsubsection{Uji Coba Fungsi}

Uji coba fungsi dilakukan dengan mencoba menekan tombol-tombol yang terdapat pada peta, seperti zoom in, zoom out, tombol pemusat, tombol direction dan tombol yang berlambangkan google.

Tabel 2 Tabel Pengujian Fungsi

\begin{tabular}{|l|l|l|l|}
\hline No. & Fungsi & Berfungsi & Tidak \\
\hline 1. & Zoom in & V & \\
\hline 2. & Zoom Out & V & \\
\hline 3. & Tombol Pemusat & V & \\
\hline 4. & Direction & V & \\
\hline 5. & Button Google & V & \\
\hline 6. & Informasi Bengkel & V & \\
\hline
\end{tabular}

Pada Tabel 2 dijelaskan bahwa fungsi dari tombol-tombol yang terdapat pada aplikasi pencarian lokasi tambal ban terdekat ini berfungsi dengan baik dan tidak ditemukannya error. Fungsi tersebut diantaranya zoom in, zoom out, pemusat, direction, button google, informasi tambal ban. Pengujian ini penting dilakukan karena fungsi tersebut merupakan bagian penting dari kemudahan pengggunaan aplikasi tambal ban.

\subsubsection{Hasil Uji Coba Pengguna}

Dari hasil uji pengguna yang dilakukan oleh 30 orang responden dengan masing-masing responden diberikan 10 pertanyaan, maka dapat dihasilkan total rata-rata persentase yang diperoleh adalah sebagai berikut :

Total rata-rata $=$ Total Presentase

$$
\begin{aligned}
& \overline{\text { Jumlah Pertanyaan }} \\
= & \frac{762,9 \%}{10} \\
= & 76,2 \%
\end{aligned}
$$

\section{$5 \quad$ Kesimpulan Dan Saran \\ 5.1 Kesimpulan}

Berdasarkan pengembangan aplikasi yang telah dilaksanakan dalam penelitian

ini, maka dapat diambil beberapa kesimpulan, diantaranya:

1. Aplikasi pencarian lokasi tambal ban dapat menampilkan data tambal ban yang telah disimpan server kedalam google map.

2. Aplikasi ini membutuhkan server database yang dapat diakses dari mana saja, sehingga membutuhkan spesifikasi server atau hosting yang memadai.

3. Aplikasi pencarian tambal ban dapat menampilkan lokasi bengkel terdekat dan ditandai dengan kedip-kedip .

4. Aplikasi pencarian bengket tambal ban dapat berjalan dengan baik pada android versi 4.4 keatas.

5. Aplikasi diuji dengan menggunakan kuisioner dengan responden berjumlah 30 orang dan dihitung menggunakan metode skala likert mendapatkan hasil $76,2 \%$, yang dimana termasuk dalam kategori baik.

\subsection{Saran}

Dalam penelitian ini penulis menyadari terdapat banyak kekurangan. Oleh karena itu, penulis menyarankan beberapa hal, antara lain:

1. Tambahkan fasilitas chat dengan pemilik bengkel tambal ban.

2. Membandingan harga termurah antar tambal ban.

3. Tambahkan petunjuk pemakaian. 
4. Tambahkan bengkel tambal ban bergerak.

5. Munculkan data bengkel hanya didalam radius saja.

\section{Daftar Pustaka}

[1] Anwar, B., H. Jaya, P.I. Kusuma, 2014, Implementast Location Based Service Berbasis Android Untuk Mengetahui Posisi User, Jurnal Ilmiah Saintikom Sains dan Komputer Vol.13 / No. 2 / Mei 2014 ISSN: 1978-6603, STMIK Triguna Dharma, Medan Johor, Sumatera Utara.

[2] Nataliana, D., 2013, Perancangan dan Realisasi Sistem Transmisi Data GPS Menggunakan Teknologi SMS (Short Messaging Service) Sebagai Aplikasi Sistem Personal Tracking, Jurnal Teknik Elektro Vol 1 / No. 1 / Januari - Juni 2013, Institut Teknologi Nasional, Bandung, Jawa Barat.

[3] Namiot, D., 2014, Geofence and Network Proximity, Faculty of Computational Math and Cybernetics, Lomonosov Moscow State University, Moscow, Rusia.

[4] Sigit, B.H., 2015, Sistem Terdistribusi Iklan Promo Gerai Waralaba Memanfaatkan Google Geofence Berbasis Android, Fakultas Teknik Informatika, Sekolah Tinggi Teknologi Adisutjipto, Yogyakarta.

[5] Erin, Y.R., 2012, Peran Sistem Informasi Android, Fakultas Teknik Informatika, Universitas Bengkulu, Fakultas Teknik, Universitas Bengkulu.

[6] Haviluddin, 2011, Memahami Penggunaan UML(Unefied Modeling Langue), FMIPA Universitas Mulawarman, Samarinda, Kalimantan Timur.

[7] Januardi, I. dan M. Rachmadi, 2015, SIG Pembagian Wilayah dengan Geofencing Berbasis Android pada Kecamata Ilir Timur II, STMIK GI MDP, Palembang.

[8] Khalim, A., H. Pringadi, dan Suwito, 2011. Rancang Bangun Sistem Pelacakan Posisi Kendaraan Menggunakan Global Positioning System (GPS). Teknik Elektro-FTI, ITS, Surabaya, Jawa Timur.

[9] Antok, C.M., 2016, Perlindungan Para Pendaki, Pemanfaatan Global Positioning System Untuk Perlindungan Pendaki Gunung Menggunakan Metode Geofence Berbasis Android, Fakultas Teknik Informatika, Sekolah Tinggi Teknologi Adisutjipto, Yogyakarta. 